EKONOMI POLITIK INSTITUSI ZAKAT: SATU PENELITIAN TERHADAP INSTITUSI ZAKAT DI PULAU PINANG

Mohammad Najwa

PRAKTIK KURBAN ONLINE DALAM PERSPEKTIF ISLAM TEBAR HEWAN KURBAN THK DI DOMPET DHUAFA

Reni Noviati

WAKAF SAHAM DITINJAU DARI HUKUM ISLAM DAN PERATURAN PERUNDANGUNDANGAN SETELAH BERLAKUNYA UNDANG-UNDANG NOMOR 41

TAHUN 2004 TENTANG WAKAF

Gusva Havita dan Gestivia Hakim

KARAKTERISTIK ENTREPRENEUR SYARIAH PADA USAHA MIKRO, KECIL, DAN MENENGAH (UMKM) DI BOGOR

Siti Usniah dan Anas Alhifni

ALTERNATIF SOLUSI ATAS PROBLEMATIKA PEMBIAYAAN MUDHARABAH

Rafidah

FAKTOR-FAKTOR YANG MEMPENGARUHI MOTIVASI MAHASISWA MENJADI ENTREPRENEUR SYARIAH

Nur Maulida Hidayat dan Anas Alhifni 
Ketua Editor :

Tuti Kurnia, SP., M.Si

Editor Pelaksana :

H. Sofian Muhlisin, LLB., LLM

Furqonul Haq, SEI., M.EI

Journal Manager :

Wildan Munawar, SEI

Jurnal Syarikah: Jurnal Ekonomi Islam adalah jurnal ilmiah yang diterbitkan untuk mendukung pengembangan ekonomi Islam. Jurnal Syarikah akan memuat artikelartikel yang terkait dengan kajian ekonomi Islam baik kajian teoritis maupun praktis. Redaksi menerima sumbangan artikel, tulisan ilmiah dari para peminat ilmiah kajian ekonomi dan keuangan syariah. Proses editing seperlunya tanpa mengubah maksud dan kandungan tulisan tersebut.

Alamat Redaksi :

Fakultas Ekonomi Islam

Universitas Djuanda Bogor

Gedung B Lantai 4

Jl. Tol Ciawi No.1 Ciawi Bogor Kode Pos 16720

Telp. (0251) 8240985

Email : fei@unida.ac.id 


\section{DAFTAR ISI}

EKONOMI POLITIK INSTITUSI ZAKAT: SATU PENELITIAN TERHADAP INSTITUSI ZAKAT DI PULAU PINANG

Mohammad Najwa

PRAKTIK KURBAN ONLINE DALAM PERSPEKTIF ISLAM TEBAR HEWAN KURBAN THK DI DOMPET DHUAFA

Reni Noviati

WAKAF SAHAM DITINJAU DARI HUKUM ISLAM DAN PERATURAN PERUNDANG-UNDANGAN SETELAH BERLAKUNYA UNDANG-UNDANG NOMOR 41 TAHUN 2004 TENTANG WAKAF

Gusva Havita, Gestivia Hakim

KARAKTERISTIK ENTREPRENEUR SYARIAH PADA USAHA MIKRO, KECIL DAN MENENGAH (UMKM) DI BOGOR

Siti Usniah, Anas Alhifni

ALTERNATIF SOLUSI ATAS PROBLEMATIKA PEMBIAYAAN MUDHARABAH

Rafidah

FAKTOR-FAKTOR YANG MEMPENGARUHI MOTIVASI MAHASISWA MENJADI ENTREPRENEUR SYARIAH

Nur Maulida Hidayat, Anas Alhifni 


\title{
WAKAF SAHAM DITINJAU DARI HUKUM ISLAM DAN PERATURAN PERUNDANG- UNDANGAN SETELAH BERLAKUNYA UNDANG-UNDANG NOMOR 41 TAHUN 2004 TENTANG WAKAF
}

\section{WAKAF STOCK REVIEWED FROM ISLAMIC LAW AND REGULATORY LAW AFTER THE REGULATION OF LAW NUMBER 41 YEAR 2004 ABOUT WAKAF}

\author{
G. Havita1; G. Hakim² \\ ${ }^{1}$ Fakultas Hukum Universitas Indonesia, Pd. Cina, Beji, Kota Depok, Jawa Barat 16424, \\ email: gusvahavita@madania.sch.id \\ ${ }^{2}$ Fakultas Ilmu Sosial dan Ilmu Poltik Universitas Indonesia, Pd. Cina, Beji, Kota Depok, Jawa \\ Barat 16424.
}

\begin{abstract}
The purpose of this research is to obtain a comprehensive analysis of the stock wakaf, the authors analyzed two main issues concerning the reasons for endowments of shares allowed under Islamic law, and Islamic law's review of the provisions of shares as an object of wakaf in the legislation after the enactment of Law No. 41 of 2004 on Wakaf. In analyzing the two main issues, the author uses descriptive method to produce descriptive analytical thesis. This study yields the conclusion that Islamic jurisprudence expert and Islamic Law Compilation, wakaf share is allowed to remember shares have conservation benefit that is in the form of dividend that can be picked up as long as the issuer company runs its business well and get profit, while the principal value of stock is maintained. Similarly, the MUI Fatwa dated May 11, 2002 on Waqf of money also permits the wakaf of shares because it sees the similarity between money and stocks, which has great potential benefits when it is represented. The review of Islamic law on shares as an object of wakaf in the legislation after the enactment of Law No. 41 of 2004 on Waqf, the conclusion that Sharia and conventional shares of halal / mubah companies may be used as wakaf objects. The permissibility of the conventional stock of the halal / mubah company to be the object of wakaf needs further regulation on the detail of the criteria and procedures for the validation so that the wakaf is still valid and provide legal certainty in the community.
\end{abstract}

Key words: Stock Wakaf, Islamic Law, Legislation

\section{ABSTRAK}

Penelitian ini bertujuan untuk memperoleh analisis yang komprehensif mengenai wakaf saham, penulis menganalisis dua pokok permasalahan yaitu mengenai alasan wakaf saham diperbolehkan menurut hukum Islam, dan tinjauan hukum Islam terhadap ketentuan saham sebagai obyek wakaf dalam peraturan perundang-undangan setelah berlakunya Undang-Undang Nomor 41 Tahun 2004 tentang Wakaf. Dalam menganalisis dua pokok permasalahan ini, penulis menggunakan metode deskriptif sehingga menghasilkan karya ilmiah yang deskriptif analitis. Penelitian ini menghasilkan kesimpulan bahwa ahli yurisprudensi Islam dan Kompilasi Hukum Islam, wakaf saham diperbolehkan mengingat saham memiliki kekekalan manfaat yaitu berupa dividen yang dapat terus dipetik selama perusahaan penerbit saham menjalankan bisnisnya dengan baik dan mendapatkan keuntungan, sementara nilai pokok dari saham tetap terjaga. Demikian juga Fatwa MUI tanggal 11 Mei 2002 tentang Wakaf uang juga memperbolehkan wakaf saham karena melihat kesamaan sifat antara uang dengan saham, yakni memiliki potensi 
kemaslahatan yang besar apabila diwakafkan. Tinjauan hukum Islam terhadap saham sebagai obyek wakaf dalam peraturan perundang-undangan setelah berlakunya UndangUndang Nomor 41 Tahun 2004 tentang Wakaf, diperoleh kesimpulan bahwa saham syariah dan saham konvensional dari perusahaan halal/mubah boleh dijadikan obyek wakaf. Kebolehan saham konvensional dari perusahaan halal/mubah untuk dijadikan obyek wakaf perlu pengaturan lebih lanjut mengenai detail kriteria-kriteria dan prosedur mewakafkannya sehingga wakaf tersebut tetap sah dan memberikan kepastian hukum di masyarakat.

Kata kunci: Wakaf Saham, Hukum Islam, Peraturan Perundang-Undangan

Havita, Gusva. 2017. Wakaf Saham Ditinjau dari Hukum Islam dan Peraturan PerundangUndangan Setelah Berlakunya Undang-Undang Nomor 41 Tahun 2004 Tentang Wakaf. Jurnal Syarikah 3 (1): 358-371.

\section{PENDAHULUAN}

Paradigma wakaf di Indonesia sejak masa penjajahan sampai era reformasi hanya dipahami secara sempit, yaitu berkisar pada wakaf yang tidak produktif dan tidak bernilai ekonomi. Hal ini tercermin dari peraturan perundangundangan tentang wakaf dan peruntukan tanah wakaf di Indonesia. (Munir: 2016)

Padahal wakaf sendiri merupakan salah satu lembaga Islam yang sangat dinamis karena sebagian besar argumentasi hukumnya berdasarkan ijtihad. Dan seiring perjalanan waktu serta lahirnya masyarakat Islam yang modern, maka wakaf pun mengalami perkembangan yang dinamis pula. Paradigma lama tentang wakaf yang lebih berkonsentrasi pada prinsip "penjagaan keabadian barang" bergeser pada paradigma baru yang lebih menekankan prinsip "pelestarian dan peningkatan manfaat wakaf". (Masruchin, 2014: 56).

Perubahan paradigma ini membawa dampak besar terhadap munculnya isu-isu wakaf kontemporer dalam kajian fikih wakaf, diantaranya: wakaf mu'aqqat (wakaf sementara), istibdal (penukaran harta benda wakaf), profesionalisasi nazhir, investasi dana wakaf dan perluasan daya jangkau obyek wakaf meliputi wakaf uang, wakaf saham, saham wakaf, wakaf HAKI, wakaf sukuk dan lain sebagainya.
Perluasan cakupan harta benda wakaf dimaksudkan untuk mengakomodasi perkembangan kebutuhan dan tuntutan masyarakat yang terus menerus. Namun terkait perluasan cakupan harta benda wakaf tersebut ternyata terdapat perbedaan pendapat dari kalangan ulama. Di antara mereka ada yang memperbolehkan ada pula yang melarangnya.

Untuk mengakomodasi kebolehan wakaf uang sebagaimana diatur dalam Fatwa MUI di atas ke dalam peraturan perundang-undangan, pemerintah kemudian menerbitkan Undang- Undang Nomor 41 Tahun 2004 tentang Wakaf. Dalam Undang-Undang No. 41 Tahun 2004 ditetapkan dua macam obyek wakaf: (1) benda benda tidak bergerak dan (2) wakaf benda bergerak. Undang-Undang Nomor 41 Tahun 2004 jelas memperluas makna harta benda wakaf (mauquf bih) yang mana tidak lagi dibatasi hanya untuk benda-benda tidak bergerak atau benda-benda tetap saja (semisal tanah dan bangunan), melainkan juga melingkupi benda bergerak selama memiliki daya tahan lama dan/atau manfaat jangka panjang serta mempunyai nilai ekonomi menurut syariah (UU No. 41 Tahun 2004). Benda bergerak yang dapat diwakafkan adalah harta benda yang tidak habis karena dikonsumsi yang mana meliputi: uang, logam mulia, surat berharga, kendaraan, hak atas kekayaan 
intelektual, hak sewa dan benda bergerak lain sesuai dengan ketentuan syariah dan peraturan perundang-undangan yang berlaku (UU No. 41 Tahun 2004).

Salah satu benda bergerak yang dapat diwakafkan dalam Peraturan Pemerintah tersebut adalah saham. Seseorang atau badan hukum yang memiliki saham dapat mengalihkan sahamnya untuk tujuan wakaf. Terkait dengan tata cara perwakafan saham, kini pemerintah telah menerbitkan Peraturan Menteri Agama Republik Indonesia (Permenag RI) Nomor 73 Tahun 2013 tentang Tata Cara Perwakafan Benda Tidak Bergerak dan Benda Bergerak Selain Uang.

Keberadaan beberapa peraturan perundang-undangan yang mengatur tentang wakaf saham sebagaimana tersebut di atas merupakan fiqh Indonesia sebagai hasil ijtihad para ulama Indonesia dengan menyesuaikan kebutuhan dan setting sosial pada saat ini. Sebab pada dasarnya hukum adalah artikulasi pemikiran dan kegiatan manusia pada zamannya. Sementara dinamika kehidupan manusia senantiasa berubah.

\section{MATERI DAN METODE}

Perkataan saham berasal dari bahasa Arab sahm atau sahmun, yang bermakna bagian. Saham merupakan bukti penyertaan modal seseorang dalam sebuah perusahaan. Saham berwujud selembar kertas yang menerangkan bahwa pemilik kertas adalah pemilik perusahaan yang menerbitkan surat berharga tersebut. Saham juga diartikan sebagai salah satu produk keuangan yang merupakan bukti kepemilikan suatu entitas, juga salah satu jenis surat berharga yang dapat diperjualbelikan di pasar modal.

Di dalam literatur tidak terdapat istilah atau pembedaan antara saham yang syariah dan non syariah.Akan tetapi, saham, sebagai bukti kepemilikan suatu perusahaan, dapat dibedakan menurut kegiatan usaha dan tujuan pembelian saham tersebut. Saham menjadi halal jika saham tersebut dikeluarkan oleh perusahaan yang kegiatan usahanya bergerak di bidang halal dan/atau dalam niat pembelian saham tersebut adalah untuk investasi, bukan untuk spekulasi.

Berikut ini adalah tabel perbandingan antara saham syariah dan saham konvensional (non-syariah):

\begin{tabular}{|c|c|}
\hline Saham Syariah & $\begin{array}{c}\text { Saham } \\
\text { Konvensional }\end{array}$ \\
\hline $\begin{array}{l}\text { Investasi terbatas } \\
\text { pada sektor tertentu } \\
\text { (sesuai dengan } \\
\text { syariah) dan tidak } \\
\text { atas dasar hutang }\end{array}$ & $\begin{array}{l}\text { Investasi bebas pada } \\
\text { semuajenis sektor } \\
\text { usaha }\end{array}$ \\
\hline $\begin{array}{lr}\text { Didasarkan } & \text { pada } \\
\text { prinsip } & \text { syariah } \\
\text { (penerapan } & \text { profit- } \\
\text { loss sharing) } & \\
\end{array}$ & $\begin{array}{l}\text { Didasarkan } \\
\text { prinsip bunga }\end{array}$ \\
\hline $\begin{array}{l}\text { Melarang berbagai } \\
\text { bentuk bunga, } \\
\text { spekulasi dan judi }\end{array}$ & $\begin{array}{l}\text { Membolehkan } \\
\text { spekulasi dan judi } \\
\text { yang pada } \\
\text { gilirannya akan } \\
\text { mendorong } \\
\text { fluktuasi pasar yang } \\
\text { tidak terkendali }\end{array}$ \\
\hline $\begin{array}{lr}\text { Adanya } & \text { shariah } \\
\text { guideline } & \text { yang } \\
\text { mengatur } & \text { berbagai } \\
\text { aspek } & \text { seperti } \\
\text { alokasi aset, praktik } \\
\text { investasi, } & \\
\text { perdagangan } & \text { dan } \\
\text { distribusi } & \\
\text { pendapatan } & \end{array}$ & $\begin{array}{l}\text { Guideline investasi } \\
\text { secara umum pada } \\
\text { produk hukum } \\
\text { pasar modal }\end{array}$ \\
\hline $\begin{array}{l}\text { Terdapat } \\
\text { mekanisme } \\
\text { screening } \\
\text { perusahaan yang } \\
\text { harus mengikuti } \\
\text { prinsip syariah }\end{array}$ & $\begin{array}{l}\text { Tidak terdapat } \\
\text { mekanisme } \\
\text { screening } \\
\text { perusahaan yang } \\
\text { harus mengikuti } \\
\text { prinsip syariah }\end{array}$ \\
\hline
\end{tabular}

Saham yang berasal dari perusahaan yang bergerak di bidang usaha yang haram jelas dilarang menurut syariah dengan mengacu pada dalil yang mengharamkan segala zat atau aktivitas tersebut. Misalnya saham perusahaan yang memproduksi minuman keras atau makanan dari babi, 
perusahaan yang bergerak dalam industri pornografi-pornoaksi dan perusahaan keuangan konvensional. Dalam hal pelarangan saham-saham dari perusahaanperusahaan tersebut fuqaha berpendapat sama.

Lantas bagaimana dengan saham konvensional yang berasal dari perusahaan yang bergerak di bidang usaha halal, semisal usaha di bidang transportasi, telekomunikasi, tekstil dan sebagainya? Beberapa fuqaha menyatakan bahwa menanam saham di perusahaan seperti ini adalah boleh secara syara'. Dalil yang menunjukkan kebolehannya adalah semua dalil yang menunjukkan kebolehan aktivitas tersebut (Yulianti: 2016). Hal ini juga sesuai dengan keputusan rapat Majlis Al-Majma' al-Fiqhy di bawah Rabithah Alam Islami (Liga Muslim Dunia) pada konferensi ke-14, yang diadakan di kota Mekah pada tanggal 21 Januari 1995.

Sehingga dapat disimpulkan bahwa tidak semua saham konvensional berasal dari perusahaan yang bergerak di sektor usaha yang diharamkan. Terdapat beberapa jenis saham yang tidak berlabel syariah namun berasal dari perusahaan halal/mubah, dan hal ini diperbolehkan oleh beberapa fuqaha. Akan tetapi terkait saham dari perusahaan halal/mubah ini masih terdapat resiko pelanggaran syariah yang mungkin terjadi. Hal ini mengingat dalam menganalisis suatu saham itu memenuhi kualifikasi sebagai saham syariah atau tidak, bukan hanya digunakan pendekatan keuangan atau produksi. Melainkan juga pendekatan-pendekatan lain seperti pendekatan pendapatan, pendekatan struktur modal dan pendekatan lainnya.

\section{Metode Penelitian}

Penelitian ini berbentuk yuridis normatif, yaitu penelitian atas hukum yang dikonsepsikan atas dasar doktrin yang dianut dan dikembangkan dalam kajiankajian hukum. Oleh karena itu merode penelitian yang digunakan adalah kualitatif. Adapun tipe penelitian yang dipakai adalah penelitian deskriptif yang bertujuan untuk memberikan gambaran mengenai wakaf saham dalam perspektif hukum Islam dan peraturan perundang-undangan setelah berlakunya Undang-Undang Nomor 41 Tahun 2004 tentang Wakaf. Jenis data yang dipakai adalah data sekunder.

\section{HASIL DAN PEMBAHASAN}

Saham merupakan salah satu macam bentuk wakaf surat berharga, dalam Fatwa MUI tanggal 11 Mei Tahun 2002 dipersamakan hukum kebolehannya dengan wakaf uang. Fatwa ini memperluas cakupan harta benda wakaf sehingga mencakup saham untuk mengakomodasi perkembangan kebutuhan dan tuntutan masyarakat yang terus menerus. Kebolehan wakaf saham mempertimbangkan potensi kemaslahatan besar apabila saham diwakafkan kemudian diambil hasilnya (dividen) yang dapat digunakan untuk kesejahteraan umum.

Wakaf itu sendiri adalah pranata keagamaan yang tidak hanya bertujuan menyediakan berbagai sarana ibadah dan sosial, tetapi juga memiliki potensi untuk memajukan kesejahteraan umum bila dikembangkan secara maksimal sesuai dengan prinsip syariah. Berdasarkan pertimbangan tersebut dan untuk memenuhi kebutuhan hukum dalam rangka pembangunan hukum nasional, pemerintah telah menerbitkan UndangUndang No. 41 Tahun 2004 tentang Wakaf.

Undang-Undang No. 41 Tahun 2004 memperluas cakupan obyek wakaf, yang mana dalam Pasal 16 ayat (1) s.d. (3) UU tersebut disebutkan bahwa jenis harta benda wakaf terdiri dari benda tidak bergerak dan benda bergerak. Pengembangan obyek wakaf hingga meliputi benda bergerak mencakup pula surat berharga, yang mana salah satunya adalah saham. Setelah berlakunya UndangUndang No. 41 Tahun 2004 tentang wakaf, terdapat dua peraturan perundangundangan lain yang juga mengatur wakaf saham, yaitu: 
1. Peraturan Pemerintah Nomor 42 Tahun 2006 tentang Pelaksanaan Undang-Undang Nomor 41 Tahun 2004 tentang Wakaf (PP No. 42 Tahun 2006)

2. Peraturan Menteri Agama Nomor 73 Tahun 2013 tentang Tata Cara Perwakafan Benda Tidak Bergerak dan Benda Bergerak Selain Uang (Permenag No. 73 Tahun 2013)

Dari ketiga peraturan perundangundangan tersebut di atas, dapat dianalisis bahwa terdapat dua jenis saham yang dapat dijadikan obyek wakaf, yaitu: (1) saham syariah dan (2) saham konvensional dari perusahaan halal/mubah.

\section{Saham Syariah Sebagai Objek Wakaf}

Saham syariah, sebagaimana definisi dalam Pasal 4 angka 2 Fatwa Dewan Syariah Nasional (DSN) No. 40/DSNMUI/X/2003 tentang Penerapan Prinsip Syariah di Bidang Pasar Modal, adalah bukti kepemilikan atas suatu perusahaan yang memenuhi kriteria sebagaimana tercantum dalam pasal 3 dan tidak termasuk saham yang memiliki hak-hak istimewa.

Yang dimaksud dengan kriteria sebagaimana tercantum dalam pasal 3 adalah sebagai berikut: (DSN MUI: 2003)

a. Jenis usaha, produk barang, jasa yang diberikan dan akad serta cara pengelolaan perusahaan emiten dan perusahaan publik yang menerbitkan efek syariah tidak boleh bertentangan dengan prinsip-prinsip syariah.

b. Jenis kegiatan usaha yang bertentangan dengan prinsip-prinsip syariah sebagaimana dimaksud dalam Pasal 3 angka 1 di atas, antara lain:

1) Perjudian dan permainan yang tergolong judi atau perdagangan yang dilarang;

2) Lembaga keuangan konvensional (ribawi), termasuk perbankan dan asuransi konvensional;

3) Produsen, distributor, serta pedagang makanan dan minuman yang haram; dan
4) Produsen, distributor, dan/atau penyedia barang-barang ataupun jasa yang merusak moral dan bersifat mudharat.

5) Melakukan investasi pada emiten (perusahaan) yang pada saat transaksi tingkat (nisbah) hutang perusahaan kepada lembaga keuangan ribawi lebih dominan dari modalnya;

a) Emiten atau perusahaan publik yang bermaksud menerbitkan efek syariah wajib untuk menandatangani dan memenuhi akad yang sesuai dengan syariah atas efek syariah yang dikeluarkan.

b) Emiten atau perusahaan publik yang menerbitkan efek syariah wajib menjamin bahwa kegiatan usahanya memenuhi prinsipprinsip syariah dan memiliki Shariah Compliance Officer.

c) Dalam hal emiten atau perusahaan publik yang menerbitkan efek syariah sewaktu-waktu tidak memenuhi persyaratan tersebut di atas, maka efek yang diterbitkan dengan sendirinya sudah bukan sebagai efek syariah.

Sedangkan yang dimaksud sahamsaham yang memiliki hak istimewa yang mana dilarang menurut syariah antara lain adalah saham preferen (saham istimewa) dan saham kosong.

Saham syariah yang listing di bursa dapat diakses pada kelompok Jakarta Islamic Index (JII) dan Indeks Saham Syariah Indonesia (ISSI). JII adalah papan indeks untuk 30 saham yang sudah dikategorikan shariah compliance atau tidak bertentangan dengan syariah (Sholihin, 2010: 253-254). Karena JII hanya menampung 30 saham terbaik yang sudah sesuai syariah, bukan berarti saham-saham lain di luar JII tidak sesuai dengan kaidah syariah. Oleh karena itulah pada 12 Mei 2011 PT Bursa Efek Indonesia meluncurkan indeks harga saham baru 
dengan nama Indeks Saham Syariah Indonesia (ISSI) yang menampung lebih banyak saham syariah. (Indeks Saham Syariah: 2016).

Saham syariah bukan hanya saham yang terdaftar dalam bursa, melainkan juga saham-saham perusahaan tertutup. Pembedaan obyek wakaf saham berupa saham syariah perusahaan terbuka/perusahan publik (saham syariah yang terdaftar di bursa) dan saham syariah perusahaan tertutup (saham syariah yang tidak terdaftar di bursa) sebagaimana diatur dalam Permenag hanyalah terkait pada tata cara mewakafkannya.

Untuk saham syariah Perseroan Terbatas Tertutup, maka nazhir hanya wajib menyampaikan AIW/APAIW (Akta Ikrar Wakaf/Akta Pengganti Akta Ikrar Wakaf) tersebut kepada perusahaan yang bersangkutan untuk dicatat sebagai wakaf atas nama nazhir. Sedangkan untuk AIW/APAIW saham syariah Perseroan Terbatas Terbuka, maka nazhir wajib menyampaikan AIW/APAIW tersebut kepada perusahaan sekuritas sebagai sub registry yang melakukan kegiatan kustodian dan menatausahakan saham syariah untuk dicatat atas nama nazhir. (Permenag No. 73 Tahun 2013).

Salah satu praktik wakaf saham di Indonesia adalah wakaf saham dengan nazhir Tabung Wakaf Indonesia (TWI). Memang mayoritas saham-saham yang diwakafkan dengan nazhir TWI adalah saham yang listing di bursa saham (saham perusahaan terbuka atau perusahaan publik). Dalam pengelolaan wakaf saham yang listing di bursa ini, TWI bekerjasama dengan BNI Securities. Namun demikian, ada satu saham yang tidak online di bursa saham, yakni saham Bank Muamalat Indonesia. TWI mengevaluasi perkembangan saham-saham yang diwakafkan tersebut setiap empat bulan sekali dengan mengedepankan aspek syariah, fundamental perusahaan dan potensi dividen yang baik (Tabung Wakaf: 2016).

\section{Saham Konvensional dari Perusahaan yang Halal/Mubah}

Permenag No. 73 Tahun 2013 memperbolehkan saham non syariah atau saham konvensional untuk diwakafkan. Namun tidak terdapat penjelasan lebih lanjut dalam Permenag tersebut mengenai kriteria saham non syariah seperti apakah yang dapat dijadikan obyek wakaf.

Dalam pembahasan yang lalu telah dijelaskan bahwa saham konvensional sebuah perusahaan yang bergerak di sektor usaha halal/mubah diperbolehkan oleh para fuqaha. Contohnya adalah saham perusahaan yang bergerak di bidang transportasi, telekomunikasi, tekstil dan sebagainya. Hal ini sesuai dengan keputusan rapat Majlis Al-Majma' al-Fiqhy di bawah Rabithah Alam Islami (Liga Muslim Dunia) pada konferensi ke-14, yang diadakan di kota Mekah pada tanggal 21 Januari 1995. Oleh karena itu, menurut analisis penulis, yang dimaksud saham konvensional sebagai obyek wakaf menurut peraturan perundang-undangan setelah berlakunya Undang-Undang Nomor 41 Tahun 2004 adalah saham konvensional dari perusahaan yang halal/mubah.

Namun, terdapat perbedaan ketentuan saham sebagai obyek wakaf dalam Peraturan Pemerintah No. 42 Tahun 2006 dan Permenag No. 73 Tahun 2013. Pasal 21 PP No. 42 Tahun 2006 menetapkan bahwa saham dapat diwakafkan selama tidak bertentangan dengan prinsip-prinsip syariah, dalam artian bahwa saham yang dapat dijadikan obyek wakaf adalah saham syariah. Sementara Permenag No. 73 Tahun 2013 menentukan bahwa saham syariah maupun saham konvensional dapat dialihkan untuk kepentingan wakaf.

Sementara itu, terkait dengan perbedaan ketentuan jenis saham yang dapat dijadikan obyek wakaf menurut PP No. 42 Tahun 2006 dan Permenag No. 73 Tahun 2013. PP No. 42 Tahun 2006 memiliki kedudukan yang lebih tinggi dan bahkan merupakan peraturan perundangundangan yang memerintahkan pembentukan Permenag tersebut, maka 
ketentuan jenis saham sebagai obyek wakaf dalam PP No. 42 Tahun 2006 lebih kuat daripada Permenag No. 73 Tahun 2013. Sehingga pemerintah, dalam hal ini Menteri Agama, harus me-review ketentuan tersebut.

Untuk memperdalam analisis hukum Islam terkait saham sebagai obyek wakaf, ada baiknya kita mengulas beberapa praktik wakaf saham di Indonesia dan Malaysia berikut ini:

a. Praktif Wakaf Saham di Indonesia

Praktik wakaf saham telah ada di masyarakat bahkan sebelum Fatwa MUI tanggal 11 Mei 2002 tentang wakaf uang dikeluarkan. Di Indonesia, tercatat bahwa wakaf saham pertama dilakukan oleh seorang wakif bernama Ibu Mus Kusmanti yang mewakafkan sejumlah saham dari 39 perusahaan kepada nazhir Tabung Wakaf Indonesia (TWI) (Fanani, 2011: 185-186). Nilai dari saham dari 39 perusahaan tersebut adalah berkisar Rp 200 juta, yang diantaranya terdapat saham dari perusahaan asuransi dan bisnis non syariah (infoanda: 2016).

Dalam awalnya, TWI menerima wakaf saham non syariah atau wakaf konvensional, yang kemudian segera dikonversi (diistibdalkan) menjadi saham syariah. Saham-saham non syariah yang dilempar ke bursa saham untuk dijual dan kemudian dibelikan saham syariah tersebut antara lain adalah saham PT. Capitalinc Finansial, PT. Panin Life Finansial, PT Bentoel International, Jakarta Internasional Hotel, BII Tbk, Sahid Jaya Hotel, Bank Arthagraha International (Tabung Wakaf: 2016). Namun praktik wakaf saham non syariah tersebut dilakukan sebelum adanya pengaturan yang lebih ketat tentang jenis saham yang boleh diwakafkan.

Saat ini Tabung Wakaf Indonesia hanya menerima wakaf saham berupa saham perusahaan syariah terbuka (terdaftar di bursa efek) dan goodwill saham perusahaan syariah tertutup (Tabung Wakaf: 2016). Mayoritas saham-saham yang diwakafkan dengan nazhir TWI adalah saham yang listing di bursa saham. Dalam pengelolaan wakaf saham yang listing di bursa ini, TWI bekerjasama dengan BNI Securities. Namun demikian, ada satu saham yang tidak online di bursa saham, yakni saham Bank Muamalat Indonesia. TWI mengevaluasi perkembangan saham-saham yang diwakafkan tersebut setiap empat bulan sekali dengan mengedepankan aspek syariah, fundamental perusahaan dan potensi deviden (bagi hasil) yang baik (Tabung Wakaf: 2016). 90\% deviden yang diperoleh dari saham itu digunakan untuk mendanai proyek-proyek sosial peningkatan kesejahteraan kaum dhuafa (sebagai mauquf 'alaih), sedangkan 10\% devidennya menjadi hak bagi nazhir (Fanani, 2011: 181).

b. Praktik Wakaf Saham di Malaysia

Wakaf saham adalah salah satu bentuk wakaf kontemporer di Malaysia, disamping wakaf tunai, saham wakaf, wakaf sukuk dan lain sebagainya. Pelaksanaan wakaf saham dan wakaf tunai di Malaysia berperan penting dalam menyediakan sumber dana untuk memajukan aset wakaf disamping memupuk budaya berwakaf dalam kalangan masyarakat (Mahmood, 2007: 6183). Disamping itu, sektor korporat dituntut agar tidak hanya mengedepankan aspek keuntungan material semata-mata tetapi juga ikut andil dalam melaksanakan wakaf (Yusof, 2010: 29-46).

Di Malaysia, wakaf diatur melalui peraturan masing-masing negara bagian. Melaka dan Johor telah melakukan kodifikasi wakaf saham dalam statuta negeri dan undang-undang di bawahnya yang masih berkaitan (Sulaiman, 2012: 153). Salah satu negara bagian yang memiliki pengaturan khsusus mengenai wakaf saham adalah Selangor. Pada tanggal 17 Juli 2014 dikeluarkan fatwa pelaksanaan wakaf saham dan keuntungan saham di kalangan syarikat korporat. Isi dari keputusan fatwa tersebut adalah sebagai berikut:

1) Pelaksanaan wakaf saham dan keuntungan saham di kalangan 
syarikat korporat yang mematuhi hukum syarak adalah harus; dan

2) Pelaksanaan pewakafan saham yang mematuhi hukum syarak bolehlah mengikut garis panduan seperti berikut:

Garis Panduan

i. Operasi syarikat

Syarikat yang ingin berwakaf hendaklah sebuah syarikat yang menjalankan operasi perniagaan yang mematuhi hukum syarak.

ii. Saham yang boleh diwakafkan

Pemilik saham syarikat yang ingin mewakafkan sahamnya di sesebuah syarikat hendaklah daripada sumber yang halal dan mematuhi hukum syarak.

iii. Keuntungkan dari saham syarikat untuk diwakafkan

Sesebuah syarikat yang memperolehi keuntungan dari operasi yang dijalankan, boleh mewakafkan keuntungan sebahagian atau keseluruhannya dengan persetujuan semua pemegang saham syarikat.

iv. Prosedur terimaan wakaf saham

Saham-saham dan keuntungan saham syarikat yang hendak diwakafkan hendaklah menggunapakai prosedur terimaan wakaf.

v. Penggunaan wakaf saham dan keuntungan saham

Kadar agihan penggunaan saham dan keuntungan saham adalah sebanyak 30\% untuk fisabilillah dan $70 \%$ untuk pelaburan dan pembangunan.

Rangka Kerja Pelaksanaan

i. Saham-saham atau keuntungan saham syarikat yang hendak diwakafkan hendaklah ditukarkan nilaiannya kepada tunai terlebih dahulu.

ii. Saham atau keuntungan saham syarikat yang telah ditukar kepada tunai seterusnya diserahkan kepada PWS. iii. Perbadanan Wakaf Selangor akan mengeluarkan resit MAIS kepada syarikat yang mewakafkan saham atau keuntungan saham syarikat.

iv. Saham-saham atau keuntungan saham syarikat yang telah ditukarkan nilainya kepada tunai akan diakaunkan ke dalam akaun wakaf asas di mana akaun ini akan digunakan untuk pembangunan aset kekal sahaja.

Fatwa pelaksanaaan wakaf saham di Selangor ini memberikan landasan kebolehan sekaligus panduan dalam pelaksanaan wakaf saham. Ditegaskan bahwa saham yang dapat dijadikan harta benda wakaf adalah saham di perusahaan yang sumbernya halal dan memenuhi prinsip syariah (saham syariah). Dalam tata cara pelaksanaan wakaf di Selangor juga ditentukan beberapa hal seperti disebutkan di atas.

Pelaksanaan wakaf saham yang paling menyita perhatian adalah wakaf saham oleh Johor Corporation Berhard (JCorp). Awalnya, JCorp mewakafkan saham Johor Land yang kemudian melalui proses istibdal dengan unit saham dalam al-'Aqar KPJ REIT (Sulaiman, 2012: 154). Yang menarik adalah, wakaf saham yang dilakukan JCorp ini dikelola oleh nazhir yang merupakan anak perusahaan di bawah JCorp sendiri, yaitu Waqaf An-Nur Corporation Berhad (WANCorp).

Pelaksanaan wakaf saham oleh JCorp dilakukan dengan mewakafkan sejumlah 200 juta ringgit Malaysia (Nilai Aset Bersih) saham dari anak perusahaan yang listing di bursa dan 50,27 juta ringgit Malaysia (Nilai Aset Bersih) saham dari anak perusahaan yang tidak listing di bursa Malaysia. Pada 29 Juni 2009, WANCorp selaku nazhir khas telah menerapkan kaedah istibdal unit saham Johor Land Berhad yang diwakafkan karena memandang unit saham ini telah dikeluarkan dari bursa Malaysia. Penggantian (istibdal) dilakukan dengan unit saham al-'Aqar KPJ REIT yang merupakan sebuah anak perusahaan JCorp yang sahamnya listing di bursa. Sehingga 
pada Desember 2009, nilai keseluruhan aset bersih saham-saham yang diwakafkan meningkat sampai dengan 282,89 juta ringgit Malaysia. Ini termasuk juga nilainilai saham dari perusahaan yang listing maupun tidak listing di bursa saham Malaysia (Manat: 2007).

Sebagai gambaran, WANCorp menggunakan manfaat deviden dari wakaf saham tersebut untuk beberapa program sosial seperti pembangunan Sumber Daya Manusia (SDM) dan kesehatan yang termasuk dalam program Corporate Social Responsibility (CSR) JCorp. Di samping proyek sosial dalam bidang kesehatan, WANCorp juga telah membangun masjid, pesantren dan rumah yatim. Selain itu, WANCorp juga menyediakan dana bantuan yang berkonsep pinjaman kebajikan (qardul hasan) yang dikenal dengan nama Wakaf Dana Niaga (WDN) disamping juga menyediakan misi bantuan bagi korban bencana.

Dalam praktik wakaf saham di Indonesia (Tabung Wakaf Indonesia) dan di Malaysia (Selangor) terdapat persamaan jenis saham yang dijadikan obyek wakaf, yaitu saham syariah. Saham syariah yang dimaksud adalah berupa saham syariah yang terdaftar di bursa maupun saham syariah perusahan syariah tertutup.

Selain terkait jenis saham yang dapat dapat dijadikan obyek wakaf, Tabung Wakaf Indonesia (TWI) dan Johor Corporation Bhd juga sama-sama mempraktikkan istibdal wakaf saham. Yaitu melakukan konversi atau menjual wakaf saham yang dianggap tidak lagi memenuhi prinsip-prinsip syariah kemudian menggantikannya dengan dibelikan saham syariah.

Praktik istibdal seperti ini memang belum diatur dalam peraturan perundangundangan di kedua Negara tersebut, namun sudah menjadi praktik yang umum. Istibdal yang diatur dalam peraturan perundangundangan di Indonesia misalnya, hanya mengatur istibdal wakaf benda tidak bergerak seperti tanah.
Istibdal, sebagai salah satu bagian dari hukum perwakafan, memang sangat dinamis, setiap waktu bi sa terjadi perubahan persepsi dan penafs iran sejalan dengan dinamika sosial. Hal ini karena sebagian besar dalildalil yang digunakan dalam fikih wakaf adalah ijtihadiyah (bersifat ijtihad) bukan qath'iyah (bersifat pasti), oleh karenanya bisa terjadi banyak perbedaan diantara ulama mujta hid (Hasan: 2016).

Dari beberapa pendapat ulama mazhab dapat disimpulkan bahwa istibdal atau mengganti benda wakaf pada dasarnya diperbolehkan, dan barang yang menggantikannya harus menjadi barang wakaf. Dalam penggantian benda wakaf tersebut terkandung kemaslahatan yang besar, terlebih lagi jika keadaan tersebut mendesak untuk dilakukan. (Musthafa, 2003: 64)

Dalam istibdal wakaf saham ini terdapat keadaan yang mendesak, yaitu bahwa saham sebagai obyek wakaf tidak lagi memenuhi prinsip syariah dan beresiko mengakibatkan wakaf menjadi tidak sah. Oleh karena itulah istibdal wakaf saham yang dilakukan nazhir tersebut boleh dilakukan untuk menjaga harta wakaf supaya tetap dapat dikelola secara syar'i dan memberikan kemaslahan kepada umat.

Dengan adanya kebolehan praktik istibdal wakaf saham ini, maka mempermudah nazhir untuk mengelola wakaf saham berupa saham konvensional dari perusahaan halal/mubah. Obyek wakaf berupa saham konvensional dari perusahaan halal/mubah yang berpotensi melanggar prinsip-prinsip syariah, misalnya dengan dikeluarkan dari bursa saham (seperti terjadi pada saham Johor Land yang dikeluarkan dari bursa saham Malaysia), dapat distibdalkan atau dikonversikan dengan saham lain yang masih memenuhi prinsip-prinsip syariah. 


\section{KESIMPULAN DAN IMPLIKASI}

\section{Kesimpulan}

1. Menurut ahli yurisprudensi Islam dan Kompilasi Hukum Islam, wakaf saham diperbolehkan mengingat saham memiliki kekekalan manfaat yaitu berupa dividen yang dapat terus dipetik selama perusahaan penerbit saham menjalankan bisnisnya dengan baik dan mendapatkan keuntungan, sementara nilai pokok dari saham tetap terjaga. Sedangkan menurut Fatwa MUI tanggal 11 Mei Tahun 2002 tentang Wakaf Uang, wakaf saham merupakan salah satu macam bentuk wakaf surat berharga, yang mana dipersamakan hukum kebolehannya dengan wakaf uang karena sama-sama memiliki potensi kemaslahatan yang besar apabila diwakafkan. Fatwa ini memperluas cakupan harta benda wakaf sehingga mencakup saham untuk mengakomodasi perkembangan kebutuhan dan tuntutan masyarakat yang terus menerus.

2. Ketentuan tentang wakaf saham dalam peraturan perundang-undangan setelah berlakunya Undang-Undang Nomor 41 Tahun 2004 menyatakan bahwa saham merupakan salah satu bagian dari surat berharga yang merupakan benda bergerak. UndangUndang Nomor 41 Tahun 2004 memang tidak secara langsung menyebutkan saham sebagai harta benda wakaf. Akan tetapi dapat disimpulkan seperti demikian karena saham termasuk dalam kategori surat berharga berdasarkan ketentuan di dalam Undang-Undang Nomor 8 Tahun 1995 tentang Pasar Modal. Sedangkan Peraturan Pemerintah Nomor 42 Tahun 2006 dan Permenag Nomor 73 Tahun 2013 menyebutkan secara enumeratif bahwa saham, sebagai salah satu kategori surat berharga, masuk dalam ruang lingkup wakaf benda bergerak selain uang karena peraturan perundang-undangan.
Terkait dengan jenis saham apa yang dapat diwakafkan, PP Nomor 42 Tahun 2006 menentukan bahwa saham dapat diwakafkan sepanjang tidak bertentangan dengan prinsip syariah atau dengan kata lain hanya saham syariah yang sah untuk dijadikan obyek wakaf. Hal ini berbeda dengan pengaturan dalam Permenag Nomor 73 Tahun 2006 yang menentukan bahwa baik saham konvensional (saham non syariah) maupun saham syariah samasama dapat diwakafkan. Saham syariah dapat dijadikan obyek wakaf sebagaimana fatwa Dewan Syariah Nasional (DSN) Nomor 40/DSNMUI/X/2003, saham syariah adalah bukti kepemilikan atas suatu perusahaan yang memenuhi kriteria sebagaimana dalam pasal 3 dan tidak termasuk saham yang memiliki hak istimewa. Selain saham syariah, saham konvensional juga dapat diwakafkan sebagaimana diatur dalam Permenag Nomor 73 Tahun 2013, dengan syarat bahwa saham konvensional tersebut berasal dari perusahaan halal/mubah. Namun Permenag ini perlu ditinjau ulang karena bertentangan dengan PP Nomor 42 Tahun 2006 yang secara tata urutan perundang-undangan memiliki kedudukan yang lebih tinggi dan bahkan merupakan peraturan perundang-undangan yang memerintahkan pembentukan Permenag tersebut. Kebolehan saham konvensional dari perusahaan halal/mubah untuk dijadikan obyek wakaf perlu pengaturan lebih lanjut mengenai detail kriteria-kriteria dan prosedur mewakafkannya sehingga wakaf tersebut tetap sah dan memberikan kepastian hukum di masyarakat.

\section{Implikasi}

1. Untuk pemerintah

a. Melakukan judicial review terhadap Permenag No. 73 Tahun 2013 karena bertentangan dengan PP No. 42 Tahun 2006 yang merupakan 
peraturan perundang-undangan yang memerintahkan pembentukan Permenag tersebut.

b. Dalam Permenag No. 73 Tahun 2013 diatur mengenai luasnya ruang lingkup jenis saham yang dapat diwakafkan, yaitu meliputi saham syariah maupun saham konvensional. Namun, Permenag ini tidak mengatur detail kriteria dan tata cara mewakafkan saham konvensional, sehingga sangat berpotensi melanggar syarat sahnya suatu obyek wakaf. Oleh karena itu, berdasarkan analisis penulis, sebaiknya dalam Permenag ini ditambahkan kriteria bahwa yang dimaksud dengan saham konvensional yang dapat dijadikan obyek wakaf adalah saham konvensional dari perusahaan yang bergerak di bidang usaha halal (misalnya usaha di bidang transportasi, telekomunikasi, tekstil dan sebagainya). Meskipun demikian, untuk obyek wakaf berupa saham konvensional dari perusahaan halal/mubah tersebut tetap berpotensi melanggar prinsipprinsip syariah, misalnya dengan dikeluarkan dari bursa saham (seperti terjadi pada saham Johor Land yang dikeluarkan dari bursa saham Malaysia). Oleh karena itu, dapat ditambahkan tata cara istibdal wakaf saham, yaitu konversi saham tersebut dengan saham lain yang masih memenuhi prinsip-prinsip syariah. Hal ini demi menjaga pengelolaan wakaf agar tetap memenuhi prinsip-prinsip syariah. Praktik istibdal wakaf saham seperti ini dapat diatur dalam peraturan perundang-undangan untuk memberikan kepastian hukum. Sedangkan untuk saham konvensional yang jelas-jelas berasal dari perusahaan yang bergerak di sektor usaha yang diharamkan oleh syara', misalnya perusahaan yang memproduksi minuman keras dan perusahaan keuangan konvensional, tidak dapat dijadikan obyek wakaf.

2. Untuk Nazhir (pengelola wakaf)

Nazhir wakaf, terutama nazhir wakaf saham, sebaiknya ikut serta melakukan gerakan sosialisasi mengajak masyarakat atau perusahaan untuk mewakafkan saham mereka. Selama ini, sosialisasi seperti ini masih sangat kurang sehingga penghimpunan wakaf saham pun kurang optimal. Namun perlu diingat bahwa nazhir memiliki kewajiban untuk melakukan pemeriksaan terhadap saham yang hendak diwakafkan, yaitu meneliti apakah saham tersebut telah memenuhi kriteria-kriteria sebagai saham syariah. Hal ini penting karena berkaitan dengan keabsahan wakaf tersebut. Selain itu nazhir wakaf saham juga harus melakukan pengelolaan wakaf saham secara profesional dengan mengedepankan aspek syariah, fundamental perusahaan dan potensi dividen yang baik.

\section{DAFTAR PUSTAKA}

Caraka, M. 2004 "Ottoman Cash Waqfs Revisited: The Case of Bursa 15551823". Journal Foundation for Science Technology and Civilisation, United Kingdom.

Hidayanto, Fajar. "Wakaf Tunai Produktif". Jurnal Mukaddimah Vol. XV No 26 Januari-Juni 2009.

Isfandiar, Ali Amin. 2008. “ Tinjauan Fiqh Muamalat dan Hukum Nasional tentang Wakaf di Indonesia". Jurnal Ekonomi Islam La_Riba Vol. II, No. 1, Juli 2008.

Lita, Helza Nova. 2012. "Kedudukan Nazhir Wakaf Saham Menurut Undang-Undang Nomor 40 Tahun 2007 tentang Perseroan Terbatas". Jurnal Wakaf dan Ekonomi Islam "AL-AWQAF" Vol. V Nomor 1 Januari 2012. Jakarta: Badan Wakaf Indonesia.

Siti Mashitoh Mahamood, "Pembentukan Dana Wakaf Menurut Perspektif Syariah 
dan Undang-Undang serta Aplikasinya di Malaysia". Jurnal Syariah 15: 2, hal. 6183, 2007.

Musthafa, "Aplikasi Metode Pembaharuan Hukum Islam dalam Undang-Undang Nomor 41 Tahun 2004 tentang Wakaf)". Jurnal Risalah Hukum Fakultas Hukum Universitas Mulawarman, Juni 2003.

Saidi, Zaimdan Hamid Abidin. 2003. "Filantropi dan Hukum di Indonesia". Jurnal Hukum "Jentera" edisi 2.

Salazehi, H.2012. "Waqf as a Social Entrepreneurship Model in Islam". International Journal of Business and Management Malaysia.

Shakor, Abd. "Pelaksanaan Pembangunan Wakaf Korporat Johor Corporation Berhard (JCorp): Satu Tinjauan". Jurnal International Conference on Humanities 2011.

Sula, M. Syakir. 2009. "Menakar Kerjasama Nazhir dengan LKS". Jurnal Al-AWQAF Jurnal Wakaf dan Ekonomi Islam Badan Wakaf Indonesia.

Sulaiman, Syahnaz. "Isu Pembangunan Wakaf Menggunakan Struktur Amanah Pelaburan Hartanah Islam di Malaysia: Satu Tinjauan". Jurnal Kanun 9 November 2012.

Syawie, Mochamad. 2011. "Kemiskinan dan Kesenjangan Sosial”. Jurnal Informasi Vol. 16 No. 03 Tahun 2011. Jakarta: Pusat Penelitian Kementerian Sosial Republik Indonesia.

Wijayanti, Asri. "Kedudukan Wakaf Berdasarkan Hukum Islam dan Perkembangannya di Indonesia". Jurnal Prespektif Hukum Vol. 3 No.1.

Yusof, Naziree Md. "Saham Wakaf Selangor: Hala Tuju dan Potensi dalam Pembangunan Masyarakat". Jurnal Kanun 2010.

Ali, Muhammad Daud. 2006. Hukum Islam: Pengantar Ilmu Hukum dan Tata Hukum Islam di Indonesia. Jakarta: PT RajaGrafindo Persada. . 2006. Sistem Ekonomi Islam Zakat dan Wakaf. Jakarta: PenerbitUniversitas Indonesia (UI-PRESS).
Ali, Muhammad Daud dan Habibah Daud. 1995. Lembaga-Lembaga Islam di Indonesia. Jakarta: PT RajaGrafindo Persada.

Ayyub, Muhammad. 2007. Understanding Islamic Finance. Inggris: John Wiley \& Sons.

Badan Wakaf Indonesia. 2012. Himpunan Peraturan Badan Wakaf Indonesia, cet. III. Jakarta: BadanWakaf Indonesia.

Basyir, A.A. 1987. Hukum Islam Tentang Wakaf, Ijarah, dan Syirkah. Bandung: AlMa'arif.

Biro Perbankan Syari'ah Bank Indonesia 2001. 2006. "Peranan Perbankan Syari'ah dalam Wakaf Tunai (Sebuah Kajian Konseptual)" dalam WAKAF TUNAI Inovasi Finansial Islam. Jakarta: PSTTI-UI.

Bisri, Cik Hasan. 2004. Pilar-Pilar Penelitian Hukum Islam dan Pranata Sosial. Jakarta: PT RajaGrafindo Persada.

Djamil, Faturrahman. "Hukum Perjanjian Syariah" Kompilasi Hukum Perikatan (Dalam Rangka Menyambut Masa Purna Bakti Usia 70 Tahun) oleh Mariam Darus Badrulzaman et.al. Bandung: PT. Citra Aditya Bakti.

Departemen Pendidikan Nasional. 2002. Kamus Besar Bahasa Indonesia. edisi 3. Jakarta: Balai Pustaka.

Dewi, Gemala dkk. 2013. Hukum Perikatan Islam di Indonesia. Jakarta: Kencana Prenada Media Group bekerjasama dengan Badan Penerbit Fakultas Hukum Universitas Indonesia.

Fyzee, A. A. A. Outlines of Muhammad Law. Delphy: Oxford University Press.

Harjono, Dhaniswara K. 2008. Pembaruan Hukum Perseroan Terbatas: Tinjauan Terhadap Undang-Undang No. 40 Tahun 2007 Tentang Perseroan Terbatas. Jakarta: Pusat Pengembangan Hukum dan Bisnis Indonesia (PPHBI).

Mamudji, Sri dkk. 2005. Metode Penelitian dan Penulisan Hukum. Jakarta: Badan Penerbit Fakultas Hukum Universitas Indonesia.

Marzuki, P.M. 2008. Penelitian Hukum. Jakarta: Kencana. 
Mubarok, Jaih. 2008. Wakaf Produktif. Bandung: Simbiosa Rekatama Media.

Nasution, Mustafa Edwin. 2006. Wakaf Tunai dan Sektor Volunteer, dalam buku Wakaf Tunai Inovasi Finansial Islam. ed. Mustafa Edwin Nasution dan Uswatun Hasanah. cet. II. Jakarta: PSTTI-UI.

Notohadiprawiro, T. 2006. Metode Penelitian dan Penulisan Hukum. Yogyakarta: Penerbit Universitas Gadjah Mada.

Prihatini, Farida dkk. 2005. Hukum Islam Zakat dan Wakaf. Jakarta: Kerjasama Penerbit Papas Sinar Mentari dengan Badan Penerbit Fakultas Hukum Universitas Indonesia.

Qahaf, Mundzir. 2008. Manajemen Wakaf Produktif. Jakarta: Khalifa (Pustaka AlKautsar Group.

Soekanto, Soerjono. 1986. Pengantar Penelitian Hukum. Jakarta: Penerbit Universitas Indonesia (UI-PRESS).

Soemitro, Rochmat. 1993. Hukum Perseroan Terbatas, Yayasan dan Wakaf. Bandung: Penerbit PT Eresco.

Subagyo, Ahmad. 2009. Kamus Istilah Ekonomi Islam. Ed. Muh. Fudhail Rahman. Jakarta: PT Gramedia.

Sudewo, Erie. 2008. Politik ZISWAF: Kumpulan Esei. Jakarta: Penerbit Universitas Indonesia (UI-Press).

Tim Penyusun. 2013. Manajemen Wakaf di Era Modern. Editor: Arif Zamhari, Cholil Nafis dan Fahruroji. Jakarta: BadanWakaf Indonesia.

Umar, M. C. $1995 . \quad$ Islam dan Tantangan Islam (Islamic and the Economis Challenge) diterjemahkan oleh Ikhwan Abidin Basri. Jakarta: Gema Insani Press.

Usman, S. 1994. Hukum Perwakafan di Indonesia. Serang: Darul Ulum Press.

Zein, Satria Effendi M. 2004. Problematika Hukum Keluarga Islam Kontemporer. Jakarta: Kencana Prenada Media Group.

Zuhaili, Wahbah. 2011. Fiqh Islam Wa Adilla Tuhu. Jilid 5. Jakarta: Gema Insani.

Indonesia. Undang-Undang Tentang Pasar Modal. UU No. 8Tahun 1995. LN No. 64 Tahun 1995. TLN No. 3608.
.Undang-Undang Tentang Wakaf. UU No. 41 Tahun 2004. LN No. 159 Tahun 2004.TLN No. 4459.

$$
\text { Undang-Undang Tentang }
$$

Perubahan Atas Undang-Undang No. 7 Tahun 1989 Tentang Peradilan Agama. UU No. 3 Tahun 2006.TLN No. 4611.

$$
\text { Undang-Undang Tentang }
$$

Penanaman Modal. UU No. 25 Tahun 2007. LN No. 67 Tahun 2007. TLN No. 4724.

. Undang-Undang Tentang Perseroan Terbatas. UU No. 40 Tahun 2007. LN No. 106 Tahun 2007. TLN No. 3587.

Peraturan Pemerintah Pelaksana Undang-Undang No. 41 Tahun 2004 tentangWakaf. PP No. 42 Tahun 2006. LN No. 105 Tahun 2064. TLN No. 4459.

. Peraturan Menteri Agama tentang Tata Cara Wakaf Benda Tidak Bergerak dan Benda Bergerak Selain Uang. Permenag No. 73 Tahun 2013. Berita Negara No. 1047 Tahun 2013.

Instruksi Presiden tentang

Penyebarluasan Kompilasi Hukum Islam. Inpres No. 1 Tahun 1991.

Peraturan Mahkamah Agung tentang Kompilasi Hukum Ekonomi Syariah. Peraturan MA No. 2 Tahun 2008.

Majelis Ulama Indonesia. Keputusan Fatwa tentang Wakaf Uang, tanggal 11 Mei 2002.

Majelis Ulama Indonesia. Fatwa Dewan Syariah Nasional (DSN) Nomor 40/DSNMUI/X/2003 tentang Pasar Modal dan Pedoman Umum Penerapan Prinsip Syariah di Bidang Pasar Modal, tanggal 4 Oktober 2003.

Hasan, Tholhah. "Istibdal Harta Benda Wakaf", $\quad$ dari http://bwi.or.id/index.php/in/publikasi Lartikel/685-istibdal-harta-bendawakaf. Diakses pada 15 November 2016 pukul 22.00 WIB.

Mannan, M.A. "Cash Waqf, Living by Giving and Sharing", dari http://www.drmannan.net/cash-waqfliving-by-giving-and-sharing-2/._Diakses 
pada tanggal 20 Februari 2016 pukul 23.30 WIB.

Mustaqimah, Noviati Endang. "Introducing Wakaf Saham, dari http://noviatiendangmustaqimah.blogs pot.com/2011/11/introducing-wakafsaham.html. Diakses pada tanggal 20 Februari 2016 pukul 22.30 WIB.

"Produk dan Layanan Pasar Modal Syariah", dari http://www.idx.co.id/idid/beranda/produkdanlayanan/pasarsy ariah.aspx. Diakses pada tanggal 10 Maret 2016 pukul 18.45 WIB.
"Profil Tabung Wakaf Indonesia", dari http://tabungwakaf.com/profil-tabungwakaf-indonesia/. Diakses pada tanggal 11 Maret 2016 pukul 20.05 WIB.

"Wakaf Saham dan Surat Berharga", dari http://tabungwakaf.com/wakaf-sahamdan-surat-berharga/. Diakses pada tanggal 20 Februari 2016 pukul 21.30 WIB.

"Wakaf Saham di TWI, Bisa", dari http://tabungwakaf.com/news/all/wak af-saham-di-twi-bisa/. Diakses pada tanggal 20 Februari 2016 pukul 22.10 WIB. 


\section{Ucapan Terima Kasih}

Dewan Redaksi serta Redaksi Pelaksana Jurnal Syarikah mengucapkan terima kasih dan penghargaan setinggi-tingginya kepada para pakar yang telah berperan sebagai mitra bebestari pada penerbitan Jurnal Syarikah Volume 3 Nomor 1 Juni Tahun 2017.

$$
\text { Dr. Nurul Huda, M.Si }
$$

Semoga kerjasama yang baik dapat terus berlangsung di masa-masa yang akan datang untuk lebih meningkatkan kualitas Jurnal Syarikah. 


\title{
PANDUAN BAGI PENULIS JURNAL SYARIKAH: JURNAL EKONOMI ISLAM
}

\author{
Pemutakhiran Juni 2017
}

\section{RUANG LINGKUP}

Jurnal Syarikah: Jurnal Ekonomi Islam mendorong pengembangkan ilmu pengetahuan dan teknologi dalam bidang Ekonomi Islam melalui penerbitan karya ilmiah berbasis hasil penelitian (orisinal).

\section{JENIS NASKAH}

Jenis naskah yang dipublikasikan adalah naskah orisinal hasil penelitian yang belum pernah dipublikasikan atau tidak sedang dalam proses publikasi oleh media publikasi lain dan terbebas dari plagiarisme. Bahasa publikasi adalah bahasa Indonesia atau bahasa Inggris. Setiap naskah yang masuk ke dewan redaksi akan menjalani proses peer-review.

Naskah hasil penelitian harus didasarkan atas data hasil penelitian orisinal yang belum dipublikasikan dan dianalisis menggunakan metode statistik. Naskah hasil penelitian yang disajikan secara deskriptif tanpa rancangan penelitian yang dikontrol oleh peneliti, naskah hasil penelitian yang hanya berupa pengulangan (replikasi) dari hasil penelitian yang telah dipublikasikan, misalnya hanya kondisi geografisnya yang berbeda, tidak akan dipertimbangkan untuk dipublikasikan. Naskah bernomor seri tidak dapat diterima, kecuali disampaikan dan disajikan pada waktu yang bersamaan.

\section{PENGIRIMAN NASKAH}

Naskah yang diajukan ditujukan ke Pimpinan Dewan Redaksi Jurnal Syarikah, melalui e-mail ke tuti.kurnia@unida.ac.id. Naskah dimaksud harus dilengkapi dengan Surat Pernyataan Orisinalitas dan Pemindahan Hak Publikasi yang ditandatangi oleh semua penulis.

\section{KONVENSI DAN KETAATASASAN}

Naskah harus ditulis dengan tema font Time New Roman 12, spasi ganda, batas tepi $2,5 \mathrm{~cm}$, halaman berukuran A4, menggunakan program microsoft office word. Naskah ditulis tidak lebih dari 7.500 kata berdasarkan urutan bagian berikut:

1) Judul (Title): JUDUL berbahasa Indonesia dan Inggris, Nama Penulis, Alamat Penulis, Penulis untuk Korespondensi, dan Judul Singkat (Running Head).

2) Tajuk Utama (main section headings): ABSTRACT, ABSTRAK, PENDAHULUAN, MATERI DAN METODE, HASIL, PEMBAHASAN, KESIMPULAN DAN IMPLIKASI, UCAPAN TERIMA KASIH, DAFTAR PUSTAKA.

3) Lampiran: Tabel, Grafik, dan Gambar.
Judul naskah harus berhuruf tebal dan kapital, ditulis pada bagian tengah dari baris tersendiri. Tajuk dan subtajuk ditulis pada baris tersendiri, mulai dari batas tepi kiri badan teks. Tajuk berhuruf tebal dan kapital. Subtajuk berhuruf tebal dan huruf kapitalnya hanya pada awal kata. Jarak antara tajuk dan subtajuk adalah 10 point (pt) sedangkan jarak antara tajuk atau subtajuk dan badan teks adalah 6 pt. Pembeda paragraf dimulai pada paragraf kedua setelah tajuk atau subtajuk dan dicirikan oleh baris pertamanya yang berjarak $0,5 \mathrm{~cm}$ dari batas tepi kiri badan teks.

Naskah yang terlalu panjang atau terlalu pendek akan dikembalikan kepada penulis. Sebagai pedoman, 7.500 kata setara dengan 34 halaman ukuran A4, yang ditulis dengan tema font Time New Roman 12, spasi ganda, marjin $2,5 \mathrm{~cm}$ dari semua tepi halaman. Judul tidak lebih dari 12 kata, Judul Singkat tidak lebih dari 50 karakter, Abstract dan Abstrak masing-masing tidak lebih dari 250 kata, key words dan kata kunci masing-masing 5 kata, dan Pendahuluan tidak lebih dari 500 kata.

\section{Judul}

Judul harus ringkas dan padat informasi, tidak memuat kata singkatan, dan memuat hal-hal berikut:

a) membangkitkan minat bagi pembaca yang memindai jurnal atau daftar judul jurnal.

b) Menyediakan informasi yang cukup bagi pembaca untuk menilai relevansi suatu naskah dengan minatnya

c) Memasukkan kata kunci atau frasa yang dapat digunakan dalam mengindeks dan menarik informasi tentang penelitian yang dilakukan.

d) Menghindari kata-kata yang tidak penting, seperti "suatu studi kasus ...." atau "suatu tinjauan empiris tentang ....". Hal-hal tersebut lebih tepat ditulis pada subbagian Materi dan Metode.

e) Tidak boleh memuat kata tempat, seperti “.... di Bogor"

\section{Nama dan Alamat Penulis}

Nama dan alamat penulis harus disajikan seperti contoh berikut:

G. PraditinKa ${ }^{1, a}$ dan W. munawar ${ }^{2}$

${ }^{1}$ Lembaga Penelitian dan Pengembangan Universitas Djuanda, Jl. Tol Ciawi Kotak Pos 35 Bogor 16720.

${ }^{2}$ Program Studi Ekonomi Islam Fakultas Ekonomi Islam Universitas Djuanda, Jl. Tol Ciawi No. 1 Kotak Pos 35 Bogor 16720.

aKorespondensi: Tuti Kurnia. Telepon: 0818106472; E-mail: tuti.kurnia@unida.ac.id 


\section{Judul Singkat (running head)}

Penulis harus menuliskan judul singkat tidak lebih dari 50 karakter termasuk ketukan kosong.

\section{Abstract dan Abstrak}

Abstract ditulis dalam bahasa Inggris baku secara konsisten (American English atau British English). Abstrak ditulis dalam bahasa Indonesia yang baik dan benar, menggunakan kata-kata baku. Baik abstract maupun abstrak dibuat dalam satu paragraf utuh tanpa ada acuan pustaka atau perujuk tabel dan/atau gambar, tidak lebih dari 250 kata. Isinya harus memuat masalah penting yang akan dipecahkan, tujuan, metode, hasil, kesimpulan, dan tidak boleh terlalu padat dengan angka-angka. Penyingkatan kata tidak diperkenankan kecuali kata dimaksud akan digunakan lebih dari satu kali..

\section{Keywords dan Kata Kunci}

Keywords (berbahasa Ingris) dan Kata kunci (berbahasa Indonesia), masing-masing tidak lebih dari lima kata dan sebaiknya tidak sama dengan kata-kata yang terdapat dalam judul naskah. Jika tidak memadai, dewan redaksi akan mengubahnya atas persetujuan penulis.

\section{Pendahuluan}

Pendahuluan yang ditulis tidak lebih dari 500 kata, harus menjelaskan isu-isu mutakhir yang mengarah pada pentingnya penelitian yang dilakukan, tujuan penelitian dinyatakan dengan jelas, dan menuliskan state of the art dari topik penelitiannya sehingga gambaran utama penelitiannya menjadi jelas bagi para pembaca. Namun, acuan pustaka dalam pendahuluan harus dibatasi karena bukan merupakan pembahasan awal.

\section{Materi dan Metode}

Materi dan metode penelitian harus dijelaskan secara terperinci pada bagian ini sehingga memungkinkan bagi peneliti lain untuk mengulang penelitian ini. Materi atau bahan yang digunakan tidak diperinci secara terpisah, melainkan harus terintegrasi dengan prosedur penelitian. Misalnya, .."responden diminta mengisi daftar pertanyaan menggunakan pensil 2B dan memilih satu dari tiga poster yang diperlihatkan oleh peneliti...", tidak perlu memerincinya seperti berikut: " Materi penelitian terdiri atas: daftar pertanyaan, pensil 2B, dan poster. Jika penelitian menggunakan produk berpemilik (seperti paten) untuk pembanding, produk dimaksud harus dituliskan dalam nama yang baku atau dituliskan merk dagangnya di dalam tanda kurung jika dianggap membantu memperjelas pemahaman pembaca, namun syaratnya harus mendapat izin tertulis dari pemilik produk dimaksud sebelum dipublikasikan. Model, tipe, merk, dan produsen peralatan yang digunakan dalam penelitian harus dijelaskan. Metode dan model analisis statistik harus jelas sehingga memungkinkan bagi peneliti lain untuk melakukan pengulangan.

Sistematika penulisannya diurutkan sebagai berikut: materi, rancangan percobaan dan perlakuan, prosedur pelaksanaan penelitian, analisis laboratorium, dan analisis statistik. Sistematika ini tidak kaku, dapat disesuaikan dengan ciri bidang keilmuan. Misalnya, untuk penelitian agribisnis yang tidak ada analisis laboratoriumnya, tidak perlu ada analisis laboratorium. Sebaliknya, subbagian lainnya dapat ditambahkan sesuai kebutuhan.

\section{Hasil dan Pembahasan}

Hasil penelitian, termasuk hasil analisis statistiknya dipaparkan secara terperinci dalam bagian ini. Ilustrasi, jika diperlukan dapat disajikan dalam bentuk tabel dan/atau gambar. Tabel dan gambar harus sederhana, informatif, mudah dipahami, dan mandiri, dalam arti tabel atau gambar dimaksud harus bisa menjelaskan kepada pembaca sehingga pembaca tidak harus membaca tulisannya untuk memahaminya. Hal yang sudah dijelaskan dalam tabel atau gambar tidak perlu diulang dalam tulisan. Tabel dan gambar dimuat pada halaman terpisah darik teks.

Hasil penelitian selanjutnya dibahas dengan cara membandingkannya dengan hasil penelitian pada topik serupa dari peneliti sebelumnya untuk mengungkap keajegannya (konsistensinya) apakah konsisten (sama) atau berbeda, lalu jelaskan alasan ilmiahnya atas hasil dimaksud secara lugas dan tuntas sehingga memperjelas posisi hasil penelitiannya. Selanjutnya, temuan hasil penelitian diungkapkan disertai kelebihan dan kelemahannya, jika ada. Ungkapan temuan hasil penelitian ini akan mempermudah dalam menyimpulkan hasil penelitian.

Data rataan perlakuan harus ditulis dengan galat bakunya (standard errors). Tingkat signifikansi statistik dapat dinyatakan dalam $\mathrm{P}<0,05, \mathrm{P}<0,01$, dan $\mathrm{P}<0,001$. Khusus pada tabel, tingkat signifikansi dimaksud, berturut-turut dapat ditulis dengan *, **, dan ${ }^{* * *}$ sedangkan pada tabel dan grafik, perbedaan antarperlakuan dapat ditunjukkan dengan huruf $a, b$ untuk $\mathrm{P}<0,05$ dan $\mathrm{A}$, B untuk $\mathrm{P}<0,01$.

\section{Kesimpulan dan Implikasi}

Kesimpulan memuat temuan hasil penelitian yang mencerminkan kebaruan, keorisinilan, kepioneran, keuniversalan, dan kontribusi ilmiah dalam pengembangan ilmu pengetahuan dan teknologi. Pernyataan dalam simpulan terbebas dari frasa atau istilah statistik, seperti " ..berpengaruh nyata $(\mathrm{P}<0,05) "$

Penulis harus menjelaskan implikasi hasil penelitiannya dalam pengembangan keilmuan, dan dampaknya terhadap lingkungan, sosial, budaya, 
ekonomi, politik, dan/atau hukum. Implikasi dipaparkan dalam bahasa yang sederhana agar pembaca noncendekia dapat memahaminya dengan mudah.

\section{Ucapan Terima Kasih}

Ucapan terima kasih hanya wajib ditulis jika penelitian didukung (biaya, sarana, tenaga) oleh instansi atau individu, atau penelaah sejawat jika naskahnya ditelaah sebelum dipublikasikan.

\section{Daftar Pustaka}

Penulis bertanggung jawab atas kebenaran semua sumber pustaka yang dirujuk dan dituliskan dalam Daftar Pustaka dan yang diacu dalam teks. Sumber pustaka sangat dianjurkan menggunakan terbitan terbaru (10 tahun terakhir), dan disajikan secara alfabet dan dituliskan menurut format nama tahun. Beberapa format dan contoh penulisannya antara lain:

Naskah jurnal atau abstrak. Format: Nama Penulis. Tahun. Judul. Nama Jurnal. Volume: Halaman. Contoh:

Rahmawati R, G Praditina dan RA Munjin. 2009. Model pelayanan rumah sakit berbasis karakteristik sosial ekonomi masyarakat untuk meningkatkan kepuasan pasien. Jurnal Humaniora. 1(1): 18-29.

Buku. Format: Nama Penulis atau Nama Editor atau Nama Lembaga. Tahun. Judul. Edisi, Nama Penerbit, Tempat Penerbitan. Contoh:

Roestamy M. 2011. Konsep-konsep hukum kepemilikan properti bagi asing (dihubungkan dengan hukum pertanahan). Edisi pertama. PT. Alumni. Bandung.

Bab buku atau proseding. Format: Nama Penulis. Tahun. Judul. Dalam: Judul buku atau proseding (Nama Editor). Volume: Halaman. Nama Penerbit, Tempat Penerbitan. Contoh:

Goulet D. 2000. Ethics, culture and development: livestock, poverty and quality of rural life. In: Livestock, ethics and quality of life (eds. Hodges, John and Han, In K). 131-154. CABI Publishing, New York, NY 10016, USA.

Laporan pada pertemuan ilmiah (konferensi, workshop, dll) yang tidak tercakup dalam buku atau proseding. Format: Nama Penulis. Tahun. Judul. Judul atau Nama Pertemuan Ilmiah, Tempat Pertemuan. Jumlah halaman. Contoh:

Jalal F. 2011. Tantangan dan peluang pendidikan di Indonesia. Orasi Ilmiah. Wisuda XXVI Sarjana dan Pascasarjana Universitas Djuanda, Bogor. 16 hal.

Tesis atau Disertasi. Format: Nama Penulis. Tahun. Judul. Tesis atau Disertasi. Nama Perguruan Tinggi, Tempat Perguruan Tinggi. Contoh:

Roestamy M. 2008. Kepastian hukum atas kepemilikan rumah dan bangunan gedung oleh investor asing dikaitkan dengan asas nasionalitas dalam sistem hukum pertanahan Indonesia. Disertasi. Program Studi Doktor Ilmu Hukum Fakultas Hukum Universitas Padjadjaran, Bandung.

Karya Ilmiah Lepas yang dimuat pada Website. Karya ilmiah lepas yang dimuat pada website hanya dapat digunakan jika literatur standard lainnya tidak tersedia. Format: Nama Penulis. Tahun. Judul. Diunduh tanggal-bulan-tahun dari http://.... Contoh:

Bryant P. 1999. Biodiversity and Conservation. Retrieved October 4, 1999 from http://darwin bio.uci.edu/ sustain/bio65/Titlpage.htm

\section{Penulisan Nama Penulis yang Diacu pada Teks}

Nama penulis yang diacu di dalam teks tidak diperkenankan menggunakan footnote. Jika jumlah penulis kurang dari tiga nama penulis ditulis semua, jika jumlah penulis tidak kurang dari tiga, hanya penulis utama yang ditulis dan diikuti dengan et al. Contoh: Syamsah (2010) menyimpulkan bahwa pajak dan zakat memiliki hubungan reduktif dan deduktabel. Parameter kualitas layanan puskesmas secara simultan mempengaruhi kepuasan pasien (Yuningsih dan Maulana 2010). Kekurangan dari kualitas pelayanan rumah sakit dapat diatasi apabila rumah sakit memperhatikan karakteristik pasien (Rahmawati et al. 2010). Tingkat kepuasan pasien menjadi indikator penting dalam mengukur kualitas pelayanan kesehatan (Yuningsih dan Maulana 2010; Rahmawati et al. 2010).

\section{Tabel}

Tabel harus dibuat sesederhana dan sesedikit mungkin, namun sekurang-kurangnya harus memuat dua baris data. Jika hanya ada satu baris data, maka penyajiannya harus menggunakan grafik. Garis horisontal tabel hanya boleh untuk mencirikan batas baris teratas (heading) dan garis terbawah dari badan tabel, sedangkan garis-garis kolom tabel tidak diperkenankan. Tabel dibuat dengan menggunakan fungsi tabel dalam program microsoft office word. Judul tabel harus ringkas, jelas, dan informatif, diberi nomor urut angka arab, huruf kapital hanya pada huruf pertama judul tabel kecuali beberapa nama diri, dan ditempatkan di atas badan tabel. Lazimnya, peubah disajikan dalam baris dan perlakuan disajikan pada kolom tabel. Keterangan tabel disajikan di bagian bawah badan tabel tanpa menuliskan kata keterangan. Di dalam teks, nomor tabel harus dirujuk, misalnya: kepribadian dalam pandangan Islam merupakan integrasi sistem kalbu, akal, dan nafsu (Tabel 1). Judul tabel, tabel dan keterangan tabel disajikan pada halaman tersendiri setelah Daftar Pustaka. Lebar tabel $80 \mathrm{~mm}$ atau $160 \mathrm{~mm}$. Jangan menyisipkan tabel pada bagian teks. Contoh Tabel lebar $80 \mathrm{~mm}$ : 
Table 1 Persentase distribusi daya fitrah nafsani dalam pembentukan kepribadian

\begin{tabular}{lccc}
\hline \multirow{2}{*}{$\begin{array}{l}\text { Daya fitrah } \\
\text { nafsani }\end{array}$} & \multicolumn{3}{c}{ Tingkat kepribadian (\%) } \\
\cline { 2 - 4 } & Muthmainnah & Lawwamah & Ammarah \\
\hline Kalbu & 55 & 30 & 15 \\
Akal & 30 & 40 & 30 \\
Nafsu & 15 & 30 & 55 \\
\hline
\end{tabular}

Format tabel diubahsuai dari Sulaiman H (2010) tanpa mengubah substansi.

\section{Gambar dan Grafik}

Gambar dan grafik dibuat dalam format JPEG dan hanya diperbolehkan jika data hasil penelitian tidak dapat disajikan dalam bentuk tabel. Grafik yang dibuat dengan program microsoft office excel harus diubahsuiakan menjadi format JPEG dengan kualitas gambar yang layak cetak. Ukuran lebar gambar adalah $80 \mathrm{~mm}$ atau $160 \mathrm{~mm}$. Judul gambar harus ringkas, jelas, dan informatif, diberi nomor urut angka arab, huruf kapital hanya pada huruf pertama judul gambar kecuali beberapa nama diri, dan ditempatkan di bagian bawah gambar. Contoh gambar berformat JPEG lebar $80 \mathrm{~mm}$ (Gambar 1).

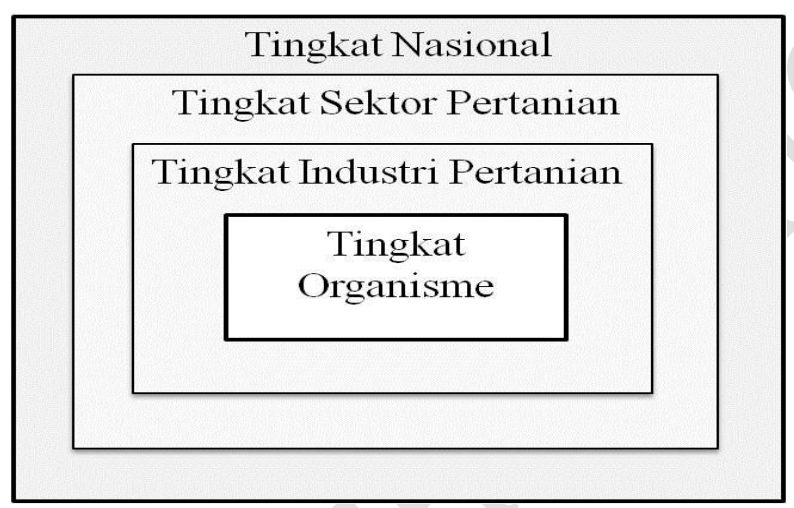

Gambar 1 Empat tingkat domain untuk menghadapi agroterorisme (ubahsuai dari Kohnen 2000).
Keterangan gambar ditulis setelah dan merupakan bagian integral dari judul gambar. Gambar dan judul gambar disajikan pada halaman tersendiri setelah halaman tabel. Di dalam teks, seluruh nomor gambar harus dirujuk secara berurutan seperti nomor tabel. Gambar dicetak hitam putih dan jika penulis menghendaki gambar berwarna, maka biaya pencetakan menjadi tanggung jawab penulis.

\section{Cetak Lepas}

Penulis yang naskahnya telah dipublikasikan akan mendapatkan satu Jurnal Humaniora dan dua eksemplar cetak lepas (reprint) artikelnya. Penulis yang ingin menambah jumlah jurnal dan cetak lepasnya dapat memesannya ke Dewan Redaksi melalui telefon atau email. Berikut ini adalah daftar harga Jurnal Humaniora dan cetak lepasnya, belum termasuk ongkos kirim.

Daftar harga Jurnal Humaniora dan cetak lepasnya

\begin{tabular}{lll}
\hline Jumlah & $\begin{array}{l}\text { Jurnal Syarikah } \\
\text { (Rp/eksemplar) }\end{array}$ & $\begin{array}{l}\text { Cetak lepasnya*) } \\
\text { (Rp/eksemplar) }\end{array}$ \\
\hline $1-5$ & 75.000 & 30.000 \\
6 atau lebih & 60.000 & 25.000 \\
\hline
\end{tabular}

${ }^{*}{ }^{6}$ pemesanan minimal 5 eksemplar. 


\section{SURAT PERNYATAAN ORISINALITAS ${ }^{1}$}

Kepada

\section{Dewan Editor Jurnal Syarikah}

Program Studi Ekonomi Islam Fakultas Ekonomi islam

Universitas Djuanda Bogor

Bersama ini kami mengajukan naskah,

\section{Judul :}

Penulis:

\begin{tabular}{|c|c|c|c|c|}
\hline No & $\begin{array}{c}\text { Penulis lengkap dengan } \\
\text { gelar akademik }\end{array}$ & Nama dan Alamat Institusi, email & $\begin{array}{l}\text { Tanda } \\
\text { Tangan }\end{array}$ & Tanggal \\
\hline
\end{tabular}

1

2

3

untuk dipublikasikan pada Jurnal Syarikah. Kami menyatakan bahwa naskah dimaksud adalah naskah orisinal hasil penelitian kami yang belum pernah dipublikasikan, tidak sedang dalam proses publikasi oleh media publikasi lainnya, tidak akan diajukan ke media publikasi lainnya selama dalam proses penelaahan (review) kecuali jika kami menarik secara resmi naskah dimaksud dari Dewan Redaksi Jurnal Syarikah, terbebas dari plagiarisme, dan kami bertanggung jawab atas seluruh substansi naskah berjudul tersebut di atas yang kami tulis.

Nama penulis untuk korespondensi:

Telepon/(hanya digunakan untuk keperluan korespondensi)

Email: (untuk keperluan korespondensi dan akan dicantumkan pada artikel yang

dipublikasikan)

Terima kasih atas perhatian dan kerjasamanya.

Tanggal:

Penulis:

Tanda tangan:

\footnotetext{
${ }^{1}$ Dikirim ke Dewan Redaksi Jurnal Syarikah, Program Studi Ekonomi Islam Fakultas Ekonomi Islam Universitas Djuanda Bogor, Gedung B Lantai IV Jl Tol Ciawi No. 1 Kotak Pos 35 Ciawi Bogor 16720, difaksimilikan ke 02518240985, dan hasil scanning-nya diemailkan ke Jurnal.Syarikah@unida.ac.id.
} 


\section{SURAT PERNYATAAN PEMINDAHAN HAK CIPTA ${ }^{2}$}

Yang bertanda tangan di bawah ini adalah penulis naskah yang berjudul:

yang diajukan untuk dipublikasikan pada Jurnal Syarikah: Jurnal Ekonomi Islam ISSN 2442-4420 menyatakan bahwa:

Kami bersedia memindahkan hak publikasi, distribusi, reproduksi, dan menjual naskah kamiyang berjudul tersebut di atas sebagai bagian dari Jurnal Syarikah kepada Dewan Redaksi Jurnal Syarikah ISSN 2442-4420

Demikian surat pernyataan ini saya buat dengan sadar, penuh rasa tanggung jawab, dan tanpa paksaan dari pihak mana pun!

\begin{tabular}{llcc}
\hline No & $\begin{array}{l}\text { Nama Penulis (lengkap } \\
\text { dengan gelar akademik) }\end{array}$
\end{tabular}$\quad$ Nama dan Alamat Institusi, email $\begin{gathered}\text { Tanda } \\
\text { Tangan }\end{gathered}$ Tanggal




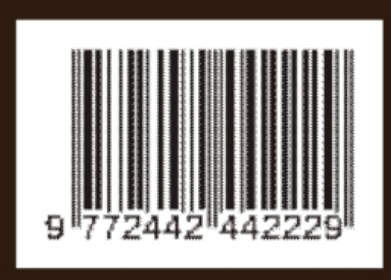

